\title{
Újabb adatok a perifériás idegek sérüléseinek szövetépítési lehetőségeiről \\ (tissue engineering) Világirodalmi áttekintés
}

\author{
DR. BÍRÓ VILMOS
}

\section{ÖSSZEFOGLALÁS}

A szerző irodalmi áttekintést nyújtó közleményében a perifériás idegsérülések kezelésének szövetépítő (tissue engineering) lehetőségeit tekinti át. Tárgyalja a korábbi és az újabb sebésztechnikai eljárásokat, majd ismerteti az ideghiányok pótlására használatos lehetőségeket: az autolog, az allogen transzplantációkat, és a tubulizációs eljárások módjait. Elemzi a növekedési faktorok szerepét és a sejt-terápia (beleértve az őssejt kezelési módszerek) felhasználását az ideggyógyulás elősegítésében. Befejezésül megállapítja, hogy az idegregenerációban szerepet játszó, nagyrészt kísérletes vizsgálatokban tanulmányozott sejtes és molekuláris folyamatok megismerése fontos lehet e sérültek eredményesebb gyógyítása céljából.

Kulcsszavak: Ideghelyreállitás; Idegtranszplantációk; Kézsérülés;

Perifériás idegsérülések; Szövetépités; Tissue engineering;

V. Bíró: New data from the possibilities of the tissue engineering in the injured peripheral nerves. Review of the literature

In his review article the author looks over the possibilities of the tissue engineering in the peripheral nerve injuries. He discusses the previous and the novel technical procedures in the surgery, and then he reviews the possibilities for the replacement of the nerve defects: autografts, allografts, and the tubulizations techniques. He analyses the functions of the growth factors and the cell therapy (including the stem-cell treating methods) in the promoting of the nerve regeneration. Finally he states, that the recognition of the mainly experimental examined cellular and molecular processes, playing role in the nerve regeneration, would be important for the treatment of these injured patients.

Keywords: $\quad$ Hand injuries - Surgery; Peripheral nerve injuries - surgery; Reconstructive surgical procedures - Methods; Tissue engineering; Transplantation, autologous; 


\section{BEVEZETÉS}

A perifériás idegrendszer finoman szervezett, bonyolult összetételű szerv, amelyet az egyes perifériás idegek alkotnak, és ez a rendszer a testben hálózatot képez. Ezen idegek anatómiai felépítésével korábbi közleményünkben (4) részletesen foglalkoztunk és utaltunk az erre vonatkozó - igen széleskörü irodalmi adatokra. Ezért e helyütt az anatómiai alapokkal nem kívánunk foglalkozni.

A közlemény címében feltüntetett kérdéskörből ez ideig számos szerző publikált adatokat, a föbb tanulmányokat munkánk irodalomjegyzékében tüntettük fel. A hazai traumatológiai-kézsebészeti szakirodalomban (40) elsőként Salamon ismertette a (magyar nyelven leginkább szövetépítésnek fordítható) tissue engineering alkalmazásának lehetőségeit (29), majd e sorok írója közölt adatokat az eljárásról (3-6). A témakörben az eddigi legátfogóbb külhoni tanulmányt Carriel és munkatársai (9), továbbá újabban Lui és szerzőtársai (17) közölték, így munkáikat vezérfonalként, alapvető közleményként használtuk fel irodalmi áttekintést nyújtó dolgozatunk megírásához.

Az idegsérülések helyreállítására is alkalmazott tissue engineering kifejezés nem más, mint olyan interdiszciplináris terület, amely arra törekszik, hogy a biológiai és a mérnöki tudományok alapelveit alkalmazva megfelelő biológiai pótlásokat hozzon létre, amelyekkel hiányzó szöveti funkciók, esetleg szervek állíthatók helyre (29). A módszer sejtkultúrában kezelt, differenciálódni képes pluripotens mesenchymalis őssejtekkel (progenitor, illetve stem cells) és szövetindukáló (szignál) polypeptidekkel (növekedési faktorok) együtt transzplantáció révén - vázszerkezet (scaffold) felhasználásával kísérli meg helyreállítani a sérült, vagy károsodott szöveteket (5). A növekedési faktorok hatására a sejtekben proteinek aktivizálódása jön létre, majd a sejtmagban gének kapcsolódhatnak be a folyamatba, amelyek szabályozzák e faktorok működését és ily módon az új szövet kialakulásának feltételei tovább javíthatók $(4-6,29)$.

\section{AZ IDEGSÉRÜLÉSEK HELYREÁLLIITÁSÁNAK LEHETŐSÉGEI}

A továbbiakban a károsodott perifériás idegek helyreállítására jelenkorban alkalmazott főbb eljárásokat és azok eredményességét tekintjük át.

\section{A sebészi technika}

Többféle mútéti eljárás ismeretes a perifériás idegsérülések helyreállítására; ezeket számos közleményben ismertették. Munkánk irodalomjegyzékében e témakör általunk fontosabbnak tartott, újabb külföldi és hazai publikációit soroltuk fel (7, 9, 10, 24, 26, 27, 30, 33-35).

A sebészi kezelésben leggyakrabban az end-to-end idegvarratot, a neurolysist, az ideg áthelyezést, illetve az end-to-side neurorrhaphiát alkalmazzák. Ideghiány esetén szóba jöhetnek az autolog, vagy az allogen (homolog) idegátültetés, illetve a tubulizációs eljárások. A neurolysis mütéte a sérült idegek belső, vagy külső leszorítása esetében, dekompressziós célból történhet. Az ideg felszabadító mútét a Sunderland (37) által módosított Seddon féle beosztás (32) szerint első fokú (neuropraxia) sérüléseknél lehet eredményes és a beavatkozás után általában helyreáll az ideg működése. Az ideg teljes átmetszése (neurotmesis) esetében mikrosebészeti technikával végzett idegvarrat szükséges $(10,33)$, azonban e beavatkozás csak akkor végezhető el, ha az idegvégek egyesítése feszülés nélkül sikerül (a defektus $<0,5 \mathrm{~cm}$ ) (10). Az idegvarrat a következő lépésekből áll: a sérült idegvégek kipreparálása és a roncsolt, károsodott részek kimetszése, egymáshoz közelítése, összeérintése, és ha ez feszülés nélkül sikerül, az összeérintett idegvégek mikrosebészeti varrattechnikával történő rögzítése. Figyelmet kell fordítani, hogy elkerüljük az idegvégek elcsavarodását; erre útmutatást adhat az epineuriumon futó egyes finom erek lefutásának egyezése a varratnál $(24,27)$. Három, különböző varratforma használatos: 1) epineuralis (1. a-c ábrák), 2) perineuralis és 3) kombinált (epineuralis és perineuralis) technika $(10,14)$. Ideális esetben az idegvarratot ajánlatos a sérülés után mihamarabb, de legkésőbb két napon belül elvégezni (8). Az idegsérülés további mútéti helyreállítási lehetősége az ideg áthelyezés (neurotizáció) és az érintett idegek között end-to-side idegvarrat, amelyet általában szekunder mútétként végeznek. A neurotizáció jól 
kidolgozott eljárás az idegsérülések kezelésére és főképpen a felső végtag proximalis részén, illetve a plexus brachialis területén használják $(10,26)$. E módszernél a donor ideg kevésbé fontos fasciculusait átmetszik, intraneuralisan (fasciculusokra bontva) szétválasztják és mikrosebészeti módszerrel összevarrják a funkcionálisan legfontosabbnak ítélt sérült distalis ideg szegmentummal. Az eljárás legfőbb hátránya a donor ideg ellátási területén fellépő funkciókiesés. A komplikált sebészi beavatkozásnak nincsenek ez ideig véglegesen kialakult irányelvei az indikációit illetően. Mindazonáltal alternatív eljárás lehet, amikor a sérült proximalis idegcsonk nem érhető el, illetve nem hozzáférhető (26). Az idegsérülések sikeres ellátásának legfontosabb eleme - kétséget kizárólag - a mikrosebészetben jártas és ebben folyamatos továbbképzést vállaló kézsebész specialista $(4,27)$.

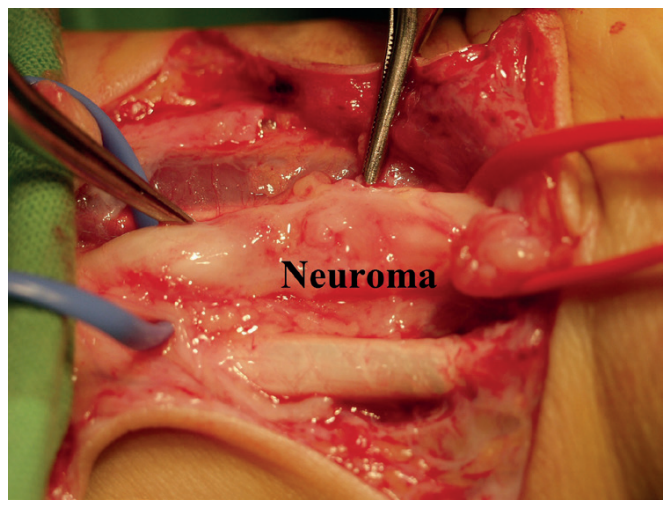

1. a ábra

8 éves fiúgyermek intézeti felvétele elött két hónappal, késsel metszette el bal csuklója volaris felszínét. A mütéti feltárásnál a teljesen átvágott nervus medianust vaskos hegszövetbe ágyazva találtuk

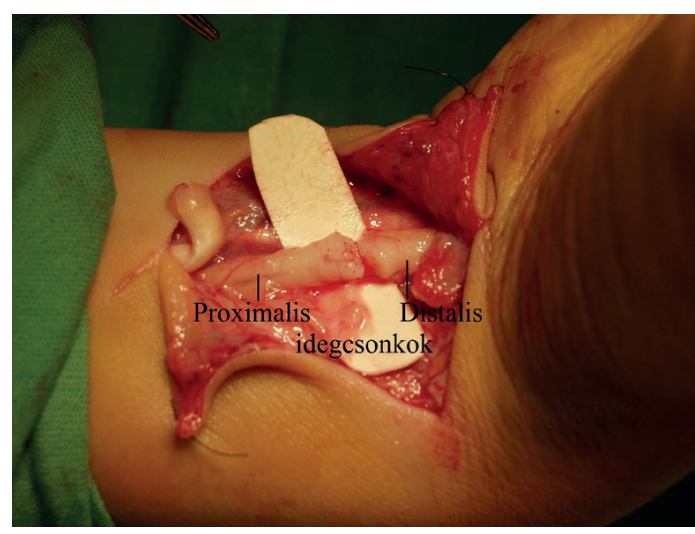

1. b ábra

Az idegvégek reszekciója után azok feszülésmentesen öszszeérinthetök voltak, igy epineuralis idegvarrat elvégzése mellett döntöttünk

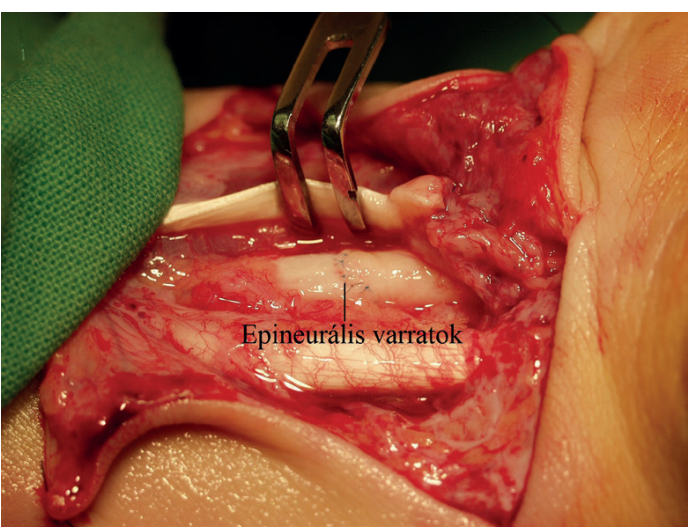

1. c ábra

Az elkészült epineuralis varrat (Mütét: Dr. Molnár László; fotó: a szerző) 


\section{Az ideghiányok áthidalására használt transzplantátumok}

Az esetek egy részében az idegsérüléseknél nem lehet feszülés mentes viszonyok mellett elvégezni az idegvarratot, mivel a károsodott idegcsonkoknak az épben történő reszekciója után defektus jön létre, vagy a sérülés eleve ideghiánnyal járt. Az idegregeneráció biztosítására ilyenkor idegtranszplantációt végeznek, amely kiküszöböli a varratvonalakban a feszülés káros hatását. Leggyakrabban autolog ideget ültetnek be (2. ábra), de felhasználásra kerülhet ideg allograft (homolog idegtranszplantátum, esetenként liofilizált formában), illetve a decellularizált allograft is $(1,10,19,26,39)$.

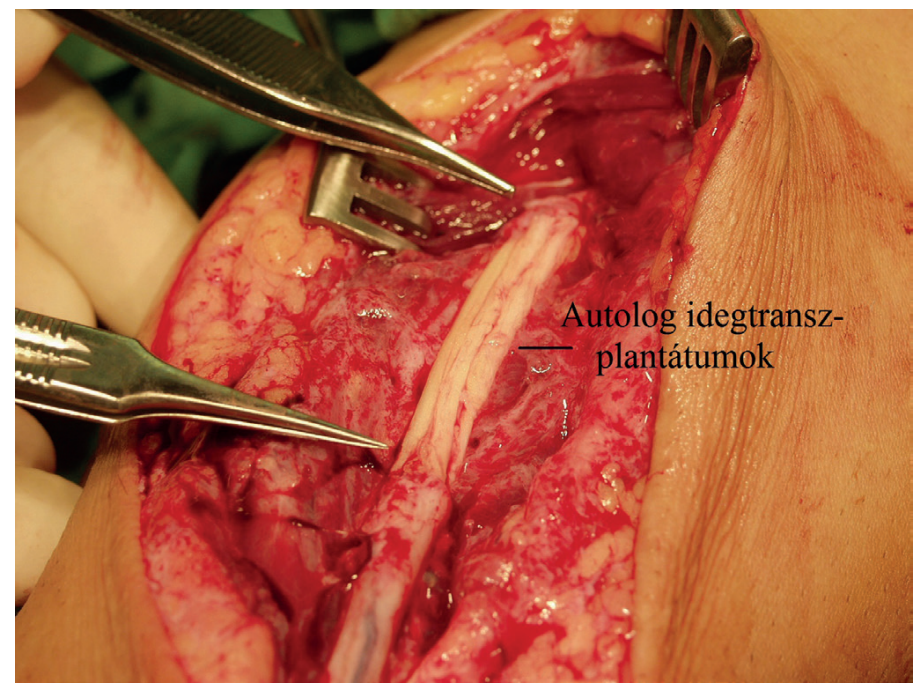

\section{2. ábra}

A jobb alkar volaris felszínén az idegdefektussal járó nervus medianus sérülését hosszú, fascicularis, autolog idegtranszplantátumokkal állítottuk helyre (Mütét: Dr. Molnár László; fotó: a szerző)

\section{Autolog transzplantátumok}

Az ideg autograftok alkalmazása az elmúlt öt évtizedben a leggyakrabban végzett mútét volt az idegdefektusok helyreállítására $(14,26)$. E transzplantátum immunológiailag semleges (inert), biztosítja a megfelelő extracellularis sejtközi állományt (mátrix), az életképes Schwann-sejteket és az axonális regenerációhoz szükséges növekedési faktorokat. A transzplantátumokat érzőidegekből nyerik, mivel a motoros idegek felhasználása erre a célra nem kívánatos $(11,14)$. A leggyakoribb donor ideg a nervus suralis, de felhasználhatók még egyéb érzőidegek is: medialis és lateralis nervus cutaneus antebrachii, a nervus ulnaris dorsalis bőrága, a comb hátsó, illetve lateralis bőridege (26). Ugyanakkor egyes irodalmi adatok szerint az ideg autotranszplantációk után mintegy 50\%-os a sikeresnek mondható esetek száma $(11,24$,$) . Ráadásul az ideg$ autograft felhasználása több hátránnyal is jár: hosszabb műtéti időtartam, magasabb ápolási költségek, az eltávolított ideg hiánya és ebből fakadóan az adó területen fájdalmas neuroma, hegesedés és érzéskiesés kialakulása $(11,14)$.

Izomzatot és vénát is felhasználtak idegvezetőként, autolog, természetes anyagként rövid idegdefektusok rekonstrukciójára (1). Kézháti, valamint véna cephalica és basilica ereket alkalmaztak digitális, $1 \mathrm{~cm}$-nél nem nagyobb idegdefektusok áthidalására (22). Az érzés helyreállása hasonló mértékben jött létre, mint a felszívódó idegvezetőknél (28). Mindazonáltal még mindig ellentmondásos a vénának, mint idegvezetőnek a használata, mivel hosszú ideghiánynál alkalmazva hajlamos lumenében a collapsusra, amely következményes idegkompresszióval és nem kielégítő végeredménnyel járhat. Az újabb kutatások során kifejlesztett izom-véna kombinált eljárás jóval hatásosabbnak bizonyult, mint a két módszer külön-külön történő alkalmazása (1, 39). E 
módszernél a véna szegmentumot teljes hoszszúságban kitöltik friss, autolog izomrostokkal. Ebben az esetben a beültetett véna (mint idegvezető) nem teszi lehetővé a proximalis idegcsonkból növekvő axonok összecsapzódását és a benne lévő vázizomzat speciális extracellularis állománya (a bazális membránnak köszönhetően) vezeti a Schwann-sejtek migrációját és így a következményes idegregenerációt $(1,13,25,39)$. E módszert érző, illetve kevert idegek defektusainál alkalmazva a sikeres eredmények közel 50\%-ot tettek ki. Azonban az eljárás jelenleg nem tudja felülmúlni a primer idegvarratok, illetve a defektusoknál az autolog idegátültetések eredményeit $(1,25)$.

\section{Ideg allograftok}

Ideg homotranszplantátumok nyerhetők (ritkán) egészséges donorokból, illetve kadáverekből (8). Az élő egyedekből eltávolított allograftok csak korlátozott hosszban vehetők $\mathrm{ki}$, ugyanakkor tetemekből kivett transzplantátumok alternatív módszernek tekinthetők a súlyosan roncsolódott, vagy defektussal járó idegsérülések rekonstrukciójában $(1,14,26)$. A homotranszplantátumok funkcionáló sejtközi állománnyal rendelkezhetnek és néha életképes Schwann-sejtek is találhatók bennük; mindezek szerepet játszanak az idegregenerációban, azonban a gazdaszervezet részéről aktív immunválaszt hoznak létre a beültetés után (26). Hasonlóan mindegyik szöveti allotranszplantációhoz, szisztémás immunoszuppressziós kezelés szükséges ezekben az esetekben, átlagosan másfél éven keresztül $(14,21)$. Ez a terápia azonban opportunista fertőzéseket, sőt - rosszabb esetben - tumor kialakulását is eredményezheti (14). Újabban jó eredménnyel végeztek idegrekonstrukciót $10 \mathrm{~cm}$-nél, kisebb idegdefektusoknál, fagyasztással tartósított allograftokkal, immunoszuppresszió nélkül (36).

$\mathrm{Az}$ utóbbi években a decellularizációs technikát írták le, mint természetes szövetből származó biológiai vázszerkezetet, a különböző szövetépítési folyamatokban (12). E módszer lényege az allograftok sejtes komponenseinek eltávolítása a szövetből, hogy megelőzzék a gazdaszervezet vezérelte rejekciót. A sejtes elemek eliminálására használhatók kémiai, fizikális, illetve kombinált eljárások, e módszerek sikeressége függ az átültetett szerv nagyságától (hosszúság, vastagság és térfogat), a sejtszámtól, továbbá több, a sejtközi állományt érintő összetevőtől. Az eljárás alkalmazása esetén kiküszöbölhetők az autolog idegek kivételi helyén visszamaradó panaszok, továbbá e graftok a kívánt hosszban és átmérőben is rendelkezésre állnak. A decellularizációt általában gamma-besugárzással végzik (9). A klinikai gyakorlatban e módszer használata sikeresnek bizonyult rövid defektussal rendelkező digitális idegeknél. Összefoglalva: számos kísérletes és klinikai tanulmány igazolta, hogy e fejezetrészben tárgyalt szövetépítő műtéti eljárás nehézség nélkül kivitelezhető, összehasonlítható és az esetek egy részében jó alternativát jelenthet az autolog idegátültetéssel, vagy az idegvezető csövek alkalmazásával szemben $(9,38)$.

\section{A tubulizációs eljárás}

Jelenleg számos szintetikus (felszívódó és nem felszívódó), továbbá természetes biológiai anyagból gyárilag készült idegvezető cső áll rendelkezésre e célból. Ezek különböző nagyságban (hosszúságban és belső átmérőben) érhetők el és használatukkal váltakozóan sikeres gyógy eredményeket publikáltak (3. ábra). 


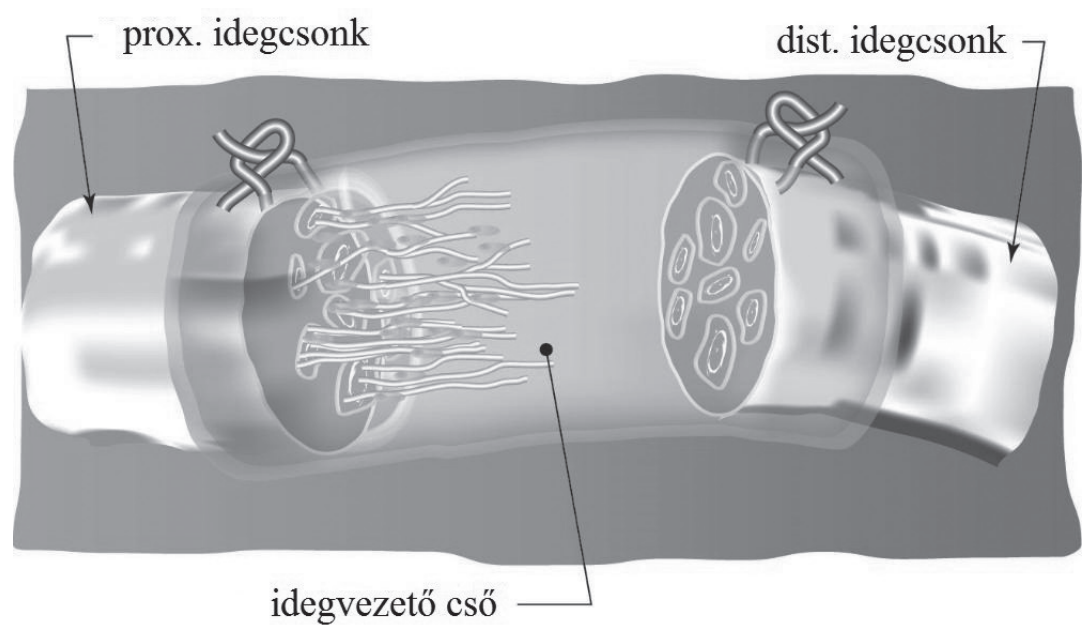

3. ábra

Idegvezető cső sémás rajza (Forrás: Internet: google: nerve conduit images - ismeretlen szerző).

\section{Szintetikus anyagok}

A szilikon szintetikus és biológiailag közömbös polimer anyag, amelyet széles körben használnak fel az orvostudományban, beleértve az idegregeneráció területét is (20). A gyógyításban a szilikon gumi vezetőcsöveket gyakran használják fel rövid $(<0,5 \mathrm{~cm})$, a nervus medianust, vagy ulnarist érintő, defektussal járó idegsérülések eseteiben, viszonylag kedvező eredményekkel. Hátránya a szilikonnak, hogy nem felszívódó anyag és idegentest reakciót válthat ki idegkompresszióval és fájdalommal; emiatt ilyenkor el kell távolítani (20, 33).

A poliészter anyagok szintetikus eredetűek és felszívódó tulajdonságokkal rendelkeznek, ezért széles körben alkalmazzák a szövetépítés területén, idegvezető csőként (28). Anyaguk lehet a polylactic acid, a poly- $\varepsilon$-caprolactone és a polyglicolic acid (31). Kísérletes vizsgálatokban kimutatták, hogy a poly-ع-caprolactone felszívódása alatt képződő bomlástermékek kevésbé toxikusak, mint a többi poliészter anyagé (14). Mégis ezen anyag beültetése után jóval nagyobb számú szövődménnyel számolhatunk, mint az autograftok esetében. Ennek oka e poliészternek a hydrophob voltában és nagyfokú rugalmatlanságában keresendő. Emiatt a varratok behelyezése nehezebb és a mútét nagyobb traumatizációt okozhat az idegen és a környező szövetekben. E szintetikus anyag fő előnye az alacsony előállítási költség és a könnyű megmunkálhatóság (9).
A poliglikolsav (polyglicolid acid-PGA) alapú idegvezető cső (9) kitűnő mechanikai tulajdonságokkal rendelkezik, amelyek komoly előnyt biztosítanak számára a mútéti kezelés során. Kísérletes vizsgálatokban azonban kimutatták, hogy az implantátum fokozatosan elveszti szilárdságát, a beültetés után 1-2 hónappal és a teljes tömege 6-12 hónap után eltűnik. Ezen felül nem ritka a környeztében kialakuló gyulladásos elváltozás, sőt a szöveti nekrózis is. Ennek ellenére a sebészeti gyakorlatban ez az idegvezető cső gyakran kerül felhasználásra. A PGA implantátumok leginkább a digitális és palmaris ideghiányok áthidalására használatosak és biztos módszert jelentenek az ujjidegek helyreállítására, amennyiben az idegvégek közötti defektus nem több $3 \mathrm{~cm}$-nél $(9,14)$.

\section{Természetes anyagok felhasználása}

Ezek az anyagok alapvetően az extracellularis szövetközi anyag (mátrix) molekuláiból épülnek fel és nagymértékben biokompatibilisek, illetve felszívódó tulajdonságokat mutatnak. E szövetben jelen lévő kollagének, a glikoproteinek és a proteoglikánok fontos szerepet játszó molekulák, amelyek a cellularis és a molekuláris folyamatokat szabályozzák. A kollagének a legfőbb rostos összetevői a sejtközi állománynak. Számos fajtájuk ismeretes, legnagyobb számban az I. típus található meg; ez a perifériás idegek nagy tömegben előforduló fehérje fajtája. 
Szerepe a Schwann-sejtek migrációjának és proliferációjának elősegítése az idegregeneráció folyamán $(9,19,20)$. A tisztított I. típusú kollagén széles körben használatos szövetépítés felhasználása céljából az idegregeneráció területén is (8). Az I. típusú kollagén alapú, gyári idegvezető csöveknek többféle változata érhető el, amelyek különböző nagyságban állnak rendelkezésre az idegdefektusok kezelésére. E készítmények mechanikailag stabilnak és hajlékonynak bizonyulnak, a lebomlás lehetőségével, amely 8 hónaptól 4 évi időtartamig végbemegy (14). A kollagén csövek felhasználása nemcsak az érző ujjidegek defektussal járó sérüléseire korlátozódik, hanem egyéb lokalizációjú idegsérülések esetében is sikerrel alkalmazták (például szülési plexus brachialis bénulás, szájüregi idegsérülések [nervus lingualis, nervus alveolaris inferior]). Összegezve: a klinikai gyakorlatban használt I. típusú kollagén-bázisú idegvezető cső minden bizonnyal a leginkább biokompatibilis és eredményei összehasonlíthatóak hatékonyságban a konvencionális („gold standard”) autolog eljárásokkal. Meg kell azonban jegyeznünk, hogy fenti megállapítás csupán a $2 \mathrm{~cm}$-nél kisebb idegdefektusok kezelése esetén érvényes (8).

\section{A tubulizációs mütéti technika előnyei és korlátai}

A tárgyalt idegvezetők használatának előnye, hogy csökken a szöveti infiltráció, a sarjszövet kialakulása, ily módon redukálva a neuroma és a hegszövet képződését, azaz a neuropátiás panaszokat és az egyéb szövődményeket. A cső formájú felépítés gondoskodik egy zárt, permeábilis mikrokörnyezetről, elősegítve a lényeges neurotrofikus faktorok koncentrálódását, így serkentve az ideg regenerációt $(18,26)$. A hagyományos sebészi eljárásokkal (beleértve az autolog idegátültetést is) összehasonlítva több előnnyel is rendelkezik: a mútétnél kevesebb öltést igényel, így az operáció ideje jelentősen rövidebb, nem szükséges egy másik mútét is (autotranszplantátum kivétele), és elkerülhetők az ideg kivételi helyén létrejövő panaszok (11). Ugyanakkor klinikailag bizonyított, hogy a felszívódó idegvezetők több hátránnyal is rendelkeznek. Elsősorban megemlítendő, hogy számos kísérleti állatnál kitûnő eredményeket regisztráltak, azonban tudni kell, hogy a regenerációs kapacitásuk jobb, és anatómiai felépítésük sem hasonlítható össze az emberével. Ezért e kísérletek eredményei csak fenntartással adaptálhatók az emberi viszonyokra. A hosszabb $(<3 \mathrm{~cm})$ idegvezető csöveknél megfigyelték, hogy az üres cső hajlamos az axonok növekedését nehezítő collapsusra (9). Egy bizonyos: rövid hiánnyal rendelkező, kis átmérőjű idegeknél a sikeres experimentális vizsgálatok után humán vonatkozásban is jó eredményeket értek el a tubulizációs technikával $(9,14)$. A növekedési faktorok idegvezető csövön belüli optimális koncentrációja az idegregeneráció szempontjából döntő és a cső hosszának és átmérőjének növelése (a megnövekedett belső térfogat) e faktorok töménységében lényeges csökkenést idéznek elő (26).

\section{Újabb fejlödési irányzatok}

A rövid idegvezető csövekben létrejövő idegregeneráció során öt fázisra bontható gyógyulási folyamatot találtak: 1) a folyadék szakaszt, ahol a lument mindkét idegcsonkból származó, növekedési faktorokban és a sejtközi állomány precursoraiban gazdag exsudatum tölti ki; 2) a sejtközi állomány (mátrix) fázis, ahol acellularis fibrin képződik; 3) a sejtes fázist, amelyre jellemző a különböző sejt-típusok proliferációja és migrációja, valamint a Schwann-sejetekből származó Büngnerkötegek kialakulása; 4) az axonalis szakaszt, ahol a proximalis idegcsonkból kinövő, a Schwann-sejtek és a nerotrofikus faktorok által vezérelt új axonok a distalis csonk identikus rostjaiba igyekeznek belenőni; 5) végül a myelinizációs fázist, amelyet jellemez az új axonok formálódó, fokozatosan kialakuló érési és myelinizációs folyamata $(9,11)$. Nagyobb idegdefektusok esetében az üres lumennel rendelkező, hosszú idegvezető csöveknél nem kielégítő mútéti végeredmények mutatkoztak. Ezek a megállapítások vezettek azután a szövetépítés újabb módszereinek a kidolgozásához: a hosszabb idegvezetők lumenét megvédve a korábban tárgyalt összeeséstől, a cső belsejét különböző, autolog szövetekkel, növekedési faktorokkal és sejtekkel töltötték fel, ily módon értek el jóval sikeresebb végeredményeket (9).

Ami az idegvezető csövek felépítését illeti, hagyományosan, a klinikai gyakorlatban 
használt idegvezetők egy vagy két (természetes, vagy szintetikus) anyagot tartalmaztak. Újabban, azzal a céllal, hogy tovább javítsák az idegregeneráció hatékonyságát, különböző biológiai anyagokat és technikákat fejlesztettek ki a tervezés és a gyártás során az újabb felszívódó és szövetbarát idegcsöveknél (2). Az idegregeneráció lefolyásában fontos szerepet játszó fibrint autolog formában használják fel az idegvezető csövek gyártásánál és jobb eredményeket értek el, mint a poly- $\varepsilon-$ hydroxybutirate alapú implantátummal. A természetes biopolimer chitosant szintén kipróbálták az ideghiányok áthidalására, a közlések szerint jó eredménnyel. A legfrissebb adatok szerint jó hatásfokkal alkalmazzák szintetikus és természetes, szövetbarát, felszívódó polimer anyagokból készült szálakból, illetve rostokból, igen finom gépi fonással előálított csöveket is, amelyeknek mikroszkopikus méretű lyukacsai lehetővé teszik a sejtes proliferációt és a migrációt. Az eredmények javítása céljából számos természetes, vagy szintetikus anyagot vizsgáltak meg az idegvezető csövek lumenének feltöltésére, hogy pótolják a hiányzó, fibrin alapú mátrixot. Kitöltő anyagként fibrint, hydrogéleket, kollagén szivacsot, rostos, vagy szálszerkezetű anyagokat használtak fel sikeresen intraluminálisan az ideg regeneráció elősegítésére (9).

\section{A növekedési faktorok szerepe}

Idegsérülések esetén számos növekedési faktor választódik ki a sérült idegcsonkokból, elindítva ezzel a teljes idegregeneráció folyamatát. A neurotrophicus faktorok három fő csoportra oszthatók fel: 1) neurotrophinok (ehhez tartozik a nerve growth factor [NGF]; a brain-derived neurotrophic factor [BDNF], a neurotrophin-3 [NT3] és a neurotrophin-4 [NT4], 2) glial-cell-derived neurotrophic factor[GDNF] és 3) a neuropoietic cytokinek (beleértve a ciliary neurotrophic factort [CNTF] is). Több tanulmány számolt be e növekedési faktorok különböző típusaival elért kedvező gyógy eredményeiről. Ezen anyagok közvetlenül beépíthetők az idegvezető csövekbe oldat bejuttatásával, vagy hordozó anyag révén $(2,11,15,23)$. Általánosságban azonban elmondható, hogy a növekedési faktorok rövid felezési idővel rendelkeznek, hatásuk gyakran dózis-függő és idővel hatásuk csökken, ezért is előnyösebb a hordozóanyagban történő bevitel: ilyenek az intraluminalis kitöltő anyagok, úgymint hydrogélek, (fibrin) fibrin szivacsok, mikrogömbök, illetve szálak, vagy rostok. A hydrogélek kombinálhatók más hordozóanyag rendszerekkel a növekedési faktorok lassú felszívódása érdekében a regenerálódó mikrokörnyezetben. A szilikon bázisú idegvezető cső, heparin hordozó anyagot tartalmazó fibrin-hydrogéllel kitöltve lehetővé tette a neurotophikus faktorok (NGF) lassú felszívódását. Ugyanerre a célra felhasználtak kollagén mátrixot is, és a közölt eredményeket jónak írták le. Mindezek a kísérletes és klinikai tapasztalatok arra engednek következtetni, hogy a növekedési faktorokkal elegyített hydrogélek szignifikáns módon segítik az ideg regenerációt, és összehasonlíthatóvá teszik e módszert az autolog idegátültetéssel. Újabban egyes neurotrophicus faktorokat (chitosan, chondroitin sulphate) az idegcsövek (poly-DLlactic acid) falába bejuttatva értek el figyelemreméltó kísérletes eredményeket (42).

\section{Sejt terápia}

A sérülés helyén található sejtek irányítják a perifériás idegregeneráció komplex folyamatát. Idegsérülést követően e sejteknek köszönhetően nagyobb mennyiségben (neurotrophikus és angiogenikus) növekedési faktorok, a sejtközi állományból molekulák valamint cytokinek szabadulnak fel a sérült idegvégekből, létrehozva optimális, regenerációs mikrokörnyezetet, amely kiváltja és támogatja az idegregenerációt (41). Ilyenkor a Schwann-sejtek számukban jelentősen (4-17-szeresen) felszaporodnak és stabil, fizikai és molekuláris szintű támogatást nyújtanak a növekvő axonoknak (8, 9, 11, 33).

\section{A Schwann-sejtek szerepe}

Jelenleg az autolog Schwann-sejtek felhasználását tartják legelőnyösebbnek a sejt alapú kezelésben, a kísérletes körülmények között vizsgált perifériás idegregeneráció kutatásában. E sejtek vezérlik a sérült ideg gyógyulását az alapvető neurotrophikus faktorok, és a sejtközi állomány molekulái révén továbbá aktív részvételük van a Waller-féle idegdegenerációban is (15). Fenti sejteket 
többféle formában alkalmazták állatkísérletekben az ideggyógyulás tanulmányozására és legelőnyösebbnek az allogen, valamint az autolog formákat találták $(8,9)$.

\section{Az őssejtek}

Az őssejtek számos fajtája használatos a biológiai, arteficiális idegvezető csövekben (bioartificial nerve conduit) alkalmazva az idegregeneráció serkentésére, elsősorban állatkísérletekben. Ezen őssejteket jellemzi az alacsony immunitás készségük és speciális szövetkultúrában képesek differenciálódni multiplex mesodermalis, neuralis és glia eredetú származékokká (16). Csontvelőből, továbbá zsírszövetből kinyert mesenchymalis őssejtek szélesebb körben kerültek felhasználásra a perifériás idegsérülések szövetépítési eljárásainál. Míg a csontvelő kinyerés viszonylag invazív eljárást igényel, addig a zsírszövet eltávolítása lényegesen egyszerűbb, leszívással is elvégezhető és valószínúleg a leggyakrabban végzett őssejt nyerési technika (9).

A sejt alapú kezeléseket sikeresen ötvözték a decellularizált idegtranszplantátumokkal. A csontvelőből nyert őssejteket fibrinnel elegyítették és befecskendezték a decellularizált ideg graft belsejébe, amellyel 1,5 cm-es ideghiányt hidaltak át. A kísérletes eredmény jónak bizonyult (43). Mindezek az eredmények alátámasztották, hogy a mesenchymalis őssejtek hatékony és összehasonlítható választási lehetőséget jelentenek a Schwann-sejt kezeléssel szemben, a kísérletes szövetépítési eljárásokban, azonban a széles körű klinikai felhasználás a jövő feladatát fogja képezni (9).

\section{MEGBESZÉLÉS}

Jelenleg többféle sebészeti módszert alkalmaznak a perifériás idegsérülések eredményes kezelésére. Az idegcsonkok közötti rövid defektus esetében a direkt helyreállítás (primer idegvarrat) a sebészek által a leggyakrabban végzett, bevált módszer és jó végeredményekkel kecsegtet. Ha ez nem végezhető el, a szakirodalomban egyre több esetet közölnek a neurotizációs mútétekről (end-to-side idgevarratokkal), elsősorban a felső végtag idegsérüléseinél. Bár ilyenkor a donor-idegen funkciókieséssel kell számolni.
A defektussal járó idegsérülések eseteiben az ideg autotranszplantátum beültetése a leginkább bevált eljárás, amely mútét után jó, vagy kitűnő végeredményre számíthatunk az érzés visszatérésénél, azonban a motoros funkciók helyreállása már nem ilyen kedvező. $\mathrm{Az}$ allograft (homotranszplantátum) hatékony alternatívát jelenthet és ideghiányoknál, számos esetben sikeres végeredményekről számoltak be. A homotranszplantátumokat beültetés előtt liofilizációs eljárással kezelve, csökkenteni tudták a recipiens szervezet részéről adott immunválaszt, ugyanakkor a graft megtartotta fizikális tulajdonságait és molekuláris struktúráját. Az utóbbi években különböző decellularizált allograftokat hoztak hivatalosan forgalomba, az USA-ban, klinikai felhasználás céljaira. Alkalmazásával a szenzoros regenerációt jónak találták, közel az egészséges szinthez. Azonban jelenleg még nem rendelkezünk elegendő ismerettel a tárgyalt, allograft-alapú módszerek hatásosságáról; ezért a kutatások folytatására és jóval több klinikai bizonyítékra van szükség az eljárás széles körű alkalmazása előtt.

A tubulizációs módszer ígéretes alternatívának látszik az idegdefektusok kezelésére. Az idegcsöveket biológiailag szövetbarát, illetve szintetikus anyagokból tervezték és gyártották, hogy zárt környezetet teremtsenek az ideg regenerációra és biztosítsák az axonok vezetését a distalis idegcsonkba, továbbá támogassák és védjék a gyógyuló ideget. Számos idegvezető cső klinikai felhasználását már hivatalosan is engedélyezte az Amerikai Élelmiszer és Gyógyszer Engedélyeztetési Hivatal (FDA), mivel nemcsak a természetes alapanyagú, hanem a szintetikus csövek alkalmazása után is jó gyógy eredményeket értek el rövid idegdefektusoknál a klinikai gyakorlatban. Sebészi vonatkozásban fontos megemlíteni, hogy e vezető csövek beültetése könnyen elsajátítható, a mútéti időtartam rövid, kevesebb öltéssel rögzíthető és a neuropathiás szövődmények előfordulása is kisebb. A sebészek leginkább kollagén alapú, illetve poliglikolsav (PGA) bázisú implantátumokat ültetnek be. A kollagén alapú cső valószínúleg a leginkább szövetbarát vezetőcső, ugyanakkor a PGA-bázisú cső kevésbé biokompatibilis, de jobb mechanikai tulajdonságokkal rendelkezik. Jelenleg széles körben elfogadott, hogy a tubulizációs technika biztos 
és hatékony választás, amikor az idegcsonkok közötti hiány nem több mint $3 \mathrm{~cm}$.

A sebészi technika és a szövetépítés (tissue engineering) jelentős fejlődése ellenére az autolog idegtranszplantátum $\mathrm{ma}$ is a leghatásosabb eljárásnak számít a nagyobb idegdefektusok pótlására. Üres idegvezető csövekkel azonban nem tudtak elérni optimális eredményeket, ugyanakkor - kísérletes körülmények között - a csőbe juttatott kitöltőkkel (fillers), növekedési faktorokkal, és a dolgozatban korábban említett sejt-bázisú módszerekkel szignifikáns javulást tapasztaltak az ideg regenerációban és a funkcionális eredményekben. Különböző biológiai anyagokat használtak fel a felszívódó csövek lumenének kitöltésére: hydrogéleket, hártyákat és szálakat. Több kísérletes tanulmány kimutatta, hogy mindezek jelentősen gyorsíthatják az idegszövet gyógyulását. Hasonló pozitívhatással járt a neurotrophikus faktorok valamint az extracelluláris mátrix molekulák alkalmazása is. Ezen molekulák serkentik a Schwann-sejtek proliferációját, a sejtes migrációt és az axonok növekedését, és ily módon gyorsítják az idegregenerációt. Megállapítható, hogy két, vagy több növekedési faktor bevitele intraluminalis kitöltővel szignifikáns javulást hoz létre kísérletes körülmények között az ideggyógyulásban, összehasonlítva az ideg autografttal. Azonban a növekedési faktorok eredményeinek mindenre kiterjedő, pontos, in vivo vizsgálata még hiányzik.

Sejt-bázisú terápiás módszerek ígéretes kezelési lehetőségként merültek fel az idegregeneráció kezelésében. A Schwann-sejtek beültetése régóta alkalmazott eljárás a kísérletes sejt-alapú szövetépítésében. Sajnálatos módon, azonban e módszer számos hátránnyal is rendelkezik, azonban ezek többsége enyhíthető az őssejtek felhasználásával.

A dolgozatban ismertetett újabb - főleg kísérletes - módszerekből igyekeztünk bemutatni az idegregeneráció felismerésében és elősegítésében ez ideig történt fejlődést, azonban jóval kevesebb negatív eredményt közlő dolgozatot találtunk, amelyek segítették volna a szakembereknek jobban megérteni a sikertelen végeredmények okait. Az elérhető adatokból nyilvánvalónak látszik, hogyha minél jobban megismerjük az idegregenerációban szerepet játszó sejtes és molekuláris folyamatokat, annál eredményesebb lesz az idegsérültjeink gyógyítása.

\section{IRODALOM}

1. Battiston B., Raimondo S., Tos P., Gaidano V, Audisio C, Scevola A, Perroteau I, Geuna S.: Chapter 11: Tissue engineering of peripheral nerves. Int. Rev. Neurobiol. 2009. 87: 227-249. https://doi.org/10.1016/S0074-7742(09)87011-6

2. Bell J. H., Haycock J. W.: Next generation nerve guides: materials, fabrication, growth factors and cell delivery. Tissue Eng. Part B. Rev. 2012. 18. (2): 116-128. https://doi.org/10.1089/ten.teb.2011.0498

3. Bíró V.: Szövetépités lehetőségei a kéz hajlitóín sérüléseinek helyreállitásában. Orv. Hetil. 2015. 156. (6): 216-220. https://doi.org/10.1556/OH.2015.30094

4. Bíró V.: A kezelési elvek fejlödése a kéz idegsérüléseinek helyreállitásában. Orv. Hetil. 2012. 153. (45): 1767-1778. https://doi.org/10.1556/OH.2012.29480

5. Bíró V.: A mesenchymalis őssejtek szerepe a kéz idegsérüléseinek helyreállitásában. Orv. Hetil. 2013. 154. (15): 574-580. https://doi.org/10.1556/OH.2013.29586

6. Bíró V.: Gondolatok a kéz idegsérüléseinek végeredményét befolyásoló tényezőkröl. Magyar Traumatológia Ortopédia Kézsebészet Plasztikai Sebészet. 2015. 58 (1): 81-85.

7. Campbell W. W.: Evaluation and management of peripheral nerve injury. Clin. Neurophysiol. 2008. 119. (9): 1951-1965. https://doi.org/10.1016/i.clinph.2008.03.018

8. Carriel V., Garzon I., Alaminos M., Campos A.: Evaluation of myelin sheath and collagen reorganization pattern in a model of peripheral nerve regeneration using an integrated histochemical approach. Histochem. Cell Biol. 2011. 136. (6): 709711. https://doi.org/10.1007/s00418-011-0874-3

9. Carriel V., Alaminos M., Garzón I., Campos A., Cornelissen M.: Tissue engineering of the peripheral nervous system. Expert Rev. Neurother. 2014. 14. (3): 201-318. https://doi.org/10.1586/14737175.2014.887444

10. Dahlin L. B.: Techniques of peripheral nerve repair. Scand J. Surg. 2008. 97. (4): $310-316$. https://doi.org/10.1177/145749690809700407

11. Daly W., Yao I., Zeugolis D., Windebank A, Pandit A.: A biomaterials approach to peripheral nerve regeneration: bridging the peripheral nerve gap and enhancing functional recovery. J. R. Soc. Interface. 2012. 9. (67): $202-221$. https://doi.org/10.1098/rsif.2011.0438

12. Gilbert T., W., Sellaro T., L., Badylak S. F.: Decellularization of tissues and organs. Biomaterials. 2006. 27. (19): $3675-3683$. 
13. Geuna S., Nicolino S., Raimondo S., Gambarotta G, Battiston B, Tos P, Perroteau I.: Nerve regeneration along bioengineered scaffolds. Microsurgery. 2007. 27. (5): 429-438. https://doi.org/10.1002/micr.20383

14. Kehoe S., Xhang X. F., Boyd D.: FDA approved guidance conduit and wraps for peripheral nerve injury: a review of materials and efficacy. Injury. 2012. 43. (5): 553-572. https://doi.org/10.1016/i.injury.2010.12.030

15. Konofaos P., Ver Halen J. P.: Nerve repair by means of tubulization: past, present, future. J. Reconstr. Microsurg. 2013.29. (3): 149-164. https://doi.org/10.1055/s-0032-1333316

16. Ladak A., Olson J., Tredget E. F., Gordon T:: Differentiation of mesenchymal stem cells to support pripheral nerve regeneration in a rat model. Exp. Neurol. 2011. 228. (2): 242-252. https://doi.org/10.1016/i.expneurol.2011.01.013

17. Lui H., Vaquette C., Bindra R.: Tissue engineering in hand surgery. A technology update. J. Hand Surg. Am. 2017. 42. (9): 727-735. https://doi.org/10.1016/j.jhsa.2017.06.014

18. Lundborg G., Longo F. M., Varon S.: Nerve regeneration model and trophic factors in vivo. Brain Res. 1982. 232. (1): 157161. https://doi.org/10.1016/0006-8993(82)90618-7

19. Lundborg G. R.: Nerve injury and repair: regeneration, reconstruction, and cortical remodelling. Philadelphia, PA., Elsevier/ Churchill Livingstone. 2004.

20. Lundborg G., Rosen B., Dahlin L. et al.: Tubular repair of the median or ulnar nerve in the human forearm.: a 5-year followup. J. Hand Surg. Br. 2004. 29. (2): 100-107. https://doi.org/10.1016/i.jhsb.2003.09.018

21. Mackinnon S., E., Doolabh V.,B., Novak C. B., Trulock E., P.: Clinical outcome following nerve allograft transplantation. Plast. Reconstr. Surg. 2001. 107. (6): 1419-1429. https://doi.org/10.1097/00006534-200105000-00016

22. Móricz O. Bíró V., Pfund Z., Tornóczky T., Vámhidy L.: Perifériás idegdefektusok kísérletes helyreállitása autológ ideg- és véna interpozitummal. Magy. Traumatol. Ortop. 1995. 38: 195-200.

23. Nectow A. R., Marra K. G., Kaplan D. L.: Biomaterials for the development of peripheral nerve guidance conduits. Tissue Eng. Part B. Rev. 2012. 18. (1): 40-50. https://doi.org/10.1089/ten.teb.2011.0240

24. Pabari A., Yang S. Y., Seifalian A. M., Mosahebi A.: Modern surgical management of peripheral nerve gap. J. Plast. Reconstr. Aesthet. Surg. 2010. 63. (12): 1941-1948. https://doi.org/10.1016/i.bips.2009.12.010

25. Raimondo S., Nicolino S., Tos P., Battiston B, Giacobini-Robecchi MG, Perroteau I, Geuna S.: Schwann cell behavior after nerve repair by means of tissue-engineered muscle-vein combined guides. J. Comp. Neurol. 2005. 489. (2): $249-259$. https://doi.org/10.1002/cne.20625

26. Ray W. Z., Mackinnon S. E.: Management of nerve gaps: autografts, nerve transfers and end-to-side neurorrhaphy. Exp. Neurol. 2010. 223. (1): 77-85. https://doi.org/10.1016/i.expneurol.2009.03.031

27. Renner A., Sántha E.: A kéz sebészete. Budapest. Kadix Press. 2014.

28. Rinker B., Liau J. Y.: A prospective randomized study comparing woven polyglycolic acid and autologous vein conduits for reconstruction of digital nerve gaps. J. Hand Surg. Am. 2011. 36. (5): 775-781. https://doi.org/10.1016/i.jhsa.2011.01.030

29. Salamon A.: Szövetpótlás biológiai és biomateriális tudományok alkalmazásával (Tissue engineering). Magyar Traumatológia Ortopédia Kézsebészet Plasztikai Sebészet. 2005. 48: 340-351.

30. Sántha E.: A perifériás idegek sérülései. In: Renner A., Sántha E.: A kéz sebészete. Budapest. Kadix Press. 2014. 281-301. p.

31. Schlosshauer B., Dreesmann L., Schaller H. E., Sinis N.: Synthetic nerve guide implants in humans: a comprehensive survey. Neurosurgery. 2006. 59. (4): 740-747. https://doi.org/10.1227/01.NEU.0000235197.36789.42

32. Seddon H.: Three types of nerve injury. Brain. 1943. 66: 237-288. https://doi.org/10.1093/brain/66.4.237

33. Siemionow M., Brzezicki G.: Chapter 8: Current techniques and concepts in peripheral nerve repair. Int. Rev. Neurobiol. 2009. 87: 141-172. https://doi.org/10.1016/S0074-7742(09)87008-6

34. Simonka J. A.: A perifériás idegsérülések ellátásával szerzett tapasztalataink (184 nagy idegtörzs- és 331 digitális idegsérülés eredményeinek értékelése). Magyar Traumatológia Ortopédia Kézsebészet Plasztikai Sebészet. 1996. 39: 59-69.

35. Simonka J. A.: Perifériás plexus és idegsérülések sebészi ellátása. In: Büki A., Szeifert Gy. (Szerk.): A neurotraumatológia alapvonalai. Budapest. Semmelweis Kiadó. 2014. 282-289. p.

36. Squintani G., Bonetti B., Paolin A., Vici D, Cogliati E, Murer B, Stevanato G.: Nerve regeneration across cryopreserved allografts from cadaveric donors: a novel approach for peripheral nerve reconstruction. J. Neurosurg. 2013. 119. (4): 907913. https://doi.org/10.3171/2013.6.JNS121801

37. Sunderland S.: Nerves and nerve injuries. 2. ed. Edinburgh. Churchill Livingstone. 1978.

38. Taras J. S., Amin N., Patel N., McCabe L. A.: Allograft reconstrucion for digital nerve loss. J. Hand Surg. Am. 2013. 38. (10): 1965-1971. https://doi.org/10.1016/j.jhsa.2013.07.008

39. Tos P., Battiston B., Ciclamini D., Geuna S, Artiaco S.: Primary repair of crush nerve injuries by means of biological tubulization with muscle-vein combined grafts. Microsurgery. 2012. 32. (5): 358-363. https://doi.org/10.1002/micr.21957

40. Vízkelety T. (föszerk.): A Magyar ortopédia, traumatológia és határterületei bibliográfiája a kezdetektöl napjainkig. Budapest. A Magyar Traumatológus Társaság, a Magyar Ortopéd Társaság, a Magyar Kézsebész Társaság és a Magyar Plasztikai Sebész Társaság Kiadványa. 2007.

41. Webber C., Zochodne D.: The nerve regenerative microenvironment: early behavior and partnership of axons and Schwann cells. Exp. Neurol. 2010. 223. (1): 51-59. https://doi.org/10.1016/i.expneurol.2009.05.037

42. Xu H., Yan Y., Li S.: PDLLA/chondroitin sulfate/chitosan/NGF conduits for peripheral nerve regeneration. Biomaterials. 2011. 32. (20): 4506-4516. $h$ ttps://doi.org/10.1016/j.biomaterials.2011.02.023 
43. Zhao Z., Wang Y., Peng J., Ren Z, Zhang L, Guo Q, Xu W, Lu S.: Improvement in nerve regeneration through a decellularized nerve graft by supplementation with bone marrow stromal cells-in-fibrin. Cell.Transplant. 2014. 23. (1): 97-110. https://doi.org/10.3727/096368912X658845

Prof. Dr. Bíró Vilmos, Ph.D., D.Sc.

7633 Pécs Hajnóczy u. 25/a.

E-mail: vilmosbirodr@gmail.com 